\title{
Community of natural lactic acid bacteria and silage fermentation of corn stover and sugarcane tops in Africa
}

\author{
Yimin Cai ${ }^{1, a, *}$, Zhumei Du ${ }^{2, a}$, Seishi Yamasaki ${ }^{1}$, Damiao Nguluve ${ }^{3}$, \\ Benedito Tinga ${ }^{3}$, Felicidade Macome ${ }^{3}$, and Tetsuji Oya ${ }^{1}$
}

\author{
* Corresponding Author: Yimin Cai \\ Tel: +81-298386365, Fax: +81-298386653, \\ E-mail: cai@affrc.go.jp \\ 1 Japan International Research Center for Agriculture \\ Sciences (JIRCAS), Tsukuba, Ibaraki 305-8686, Japan \\ ${ }^{2}$ College of Grassland Science and Technology, China \\ Agricultural University, Beijing 100193, China \\ ${ }^{3}$ Agricultural Research Institute of Mozambique, \\ Matola 999068, Mozambique \\ a They are co-first authors and contributed equally to \\ this article. \\ ORCID \\ Yimin Cai \\ https://orcid.org/0000-0003-2650-5210 \\ Zhumei Du \\ https://orcid.org/0000-0003-1288-5208 \\ Seishi Yamasaki \\ https://orcid.org/0000-0003-4376-7642 \\ Damiao Nguluve \\ https://orcid.org/0000-0001-6391-7295 \\ Benedito Tinga \\ https://orcid.org/0000-0002-3008-6795 \\ Felicidade Macome \\ https://orcid.org/0000-0002-0413-4335 \\ Tetsuji Oya \\ https://orcid.org/0000-0002-7839-7517
}

Submitted Apr 25, 2019; Revised Aug 27, 2019; Accepted Oct 17, 2019
Objective: To effectively utilize crop by-product resources to address the shortage of animal feed during the dry season in Africa, the community of natural lactic acid bacteria (LAB) of corn stover and sugarcane tops and fermentation characteristics of silage were studied in Mozambique.

Methods: Corn stover and sugarcane tops were obtained from agricultural field in Mozambique. Silage was prepared with LAB inoculant and cellulase enzyme and their fermentation quality and microbial population were analyzed.

Results: Aerobic bacteria were the dominant population with $10^{7}$ colony-forming unit/g of fresh matter in both crops prior to ensiling, while $10^{4}$ to $10^{7} \mathrm{LAB}$ became the dominant bacteria during ensiling. Lactobacillus plantarum was more than $76.30 \%$ of total isolates which dominated silage fermentation in the LAB-treated sugarcane top silages or all corn stover silages. Fresh corn stover and sugarcane tops contain $65.05 \%$ to $76.10 \%$ neutral detergent fiber (NDF) and $6.52 \%$ to $6.77 \%$ crude protein $(\mathrm{CP})$ on a dry matter basis, and these nutrients did not change greatly during ensiling. Corn stover exhibits higher LAB counts and watersoluble carbohydrates content than sugarcane top, which are naturally suited for ensiling. Meanwhile, sugarcane tops require LAB or cellulase additives for high quality of silage making.

Conclusion: This study confirms that both crop by-products contain certain nutrients of $\mathrm{CP}$ and NDF that could be well-preserved in silage, and that they are potential roughage resources that could cover livestock feed shortages during the dry season in Africa.

Keywords: Corn Stover; Lactic Acid Bacteria; Microbial Population; Silage Fermentation; Sugarcane Top

\section{INTRODUCTION}

The major constraint for cows in the tropics is shortage of feed in terms of quality and quantity, especially in the dry season [1]. The main roughage sources for cows in Africa are native grasses and agricultural by-products. When cows are not fed such quality roughage, decreased milk and meat production results [2]. In recent years, improved technologies for producing forage crops, grasses, and crop by-products have been investigated, and their adaptability to various conditions, nutritive value, and contribution to animal productivity explored [3]. Several factors can influence crops nutrition, such as plant genotype, sowing density, harvest season, irrigation and fertilization. Generally, tropical crops can only be grown during the rainy season and the bulk of by-product production occurs after harvest. Crop by-products should be preserved to ensure a continuous supply of feed for ruminants during the dry season. Improved silage preparation and storage are the most effective techniques for ensuring that the animal production system can cope with animal feed shortages 
in the tropics [1].

Corn (Zea mays L.) and sugarcane (Saccharum officinarum L.) are important crops for food and sugar production in Africa, and they were produced approximately 1.45 million tons and 2.76 million tons annually, respectively in Mozambique [4]. When corn is harvested for grain, more than $40 \%$ dry matter (DM) of the corn plant, including the leaves, stalks, husks, and cobs, are discarded in the field [5]. Sugarcane top as residue represent $15 \%$ to $25 \%$ of the aerial part of the plant [6]. Therefore, corn stover and sugarcane tops are among the main agricultural by-products produced in Africa, but they are generally discarded in the field, where they are often burned and used as fertilizer [7].

The by-products of both corn and sugarcane could be used for livestock feed, as they are cheap and abundant in the tropics, where other green fodder is unavailable. The preservation of forage crops, as silage, depends on the production of sufficient acid to inhibit the activity of contaminating microbes under anaerobic conditions [8]. Usually, it is difficult to make tropical forage crops and grasses of high fermentation quality due to their high moisture and low watersoluble carbohydrates (WSC) contents [2]. Better technologies aimed at creating good-quality animal feed, by providing longterm storage of silage from crop by-products, need to be developed. The improvement of ensiling techniques through use of biological additives, such as lactic acid bacteria (LAB) inoculants and cellulose, is widely anticipated. It is well-accepted that these silage additives could improve silage preservation efficiency and thereby enhance cattle performance [9]. In general, cellulase improves fibre degradation by increasing the WSC as a substrate for LAB, which then produce lactic acid. As a result, the $\mathrm{pH}$ decreases, preserving the forage crops.

Ensiling methods for creating good-quality silage and longterm storage are not available year-round in the tropics [1]. However, there is limited information available on epiphytic $\mathrm{LAB}$ characteristics and silage fermentation in Africa. In the present study, we identified and characterised LAB isolated from fresh corn stover and sugarcane tops in Mozambique, and then determined their ensiling characteristics. To improve fermentation quality, the silages were prepared with microbial additives, including LAB inoculants and cellulase enzymes, which are likely to play an important role in improving silage fermentation.

\section{MATERIALS AND METHODS}

\section{Ensiling materials and silage preparation}

Corn stover and sugarcane tops were obtained from agricultural field in a corn-production area and in an industrial sugar-production region in Maputo, Mozambique on September 2018, respectively. After harvest, fresh corn stover and sugarcane tops were immediately cut into 1 to $2 \mathrm{~cm}$ lengths by a chopper (92-2S, Sida Agri-Machine Co., Ltd, Luoyang, China), and approximately $8 \mathrm{~kg}$ were packed into 20 L polyethylene drum (Ka-Kosher Co., Ltd, Sinaloa, Mexico) silos. The silos were kept at an ambient temperature $\left(25^{\circ} \mathrm{C}\right.$ to $38^{\circ} \mathrm{C}$ ) and opened after $60 \mathrm{~d}$ of ensiling for analysis of fermentation quality and microbial analysis [10]. The experiment was designed as a $2 \times 4$ factorial arrangement in a completely randomized design (crop by-products $\times$ additive treatments) with triple replicates per treatment. The commercial LAB inoculant FG (Lactobacillus plantarum, Snow Brand Seed Co., Ltd, Sapporo, Japan) and Acremonium cellulase (Acremonium cellulase, Meiji Seika Pharma Co., Ltd, Tokyo, Japan) were used as silage additives based on the guidelines of a commercial manufacturer. Inoculant strain originally isolated from forage crop that could produce more lactic acid in the silage environment. Cellulase is produced from Acremonium cellulolyticus, the main compositions are glucanase and pectinase, carboxymethyl cellulase activity is $7,350 \mathrm{U} / \mathrm{g}$. The LAB were inoculated at $5 \mathrm{mg} / \mathrm{kg}$ as $1.0 \times 10^{5}$ colony-forming unit $(\mathrm{cfu}) / \mathrm{g}$ on a fresh matter (FM) basis. Cellulase was added at $10 \mathrm{mg}$ blended with 20 $\mathrm{mL} \mathrm{H}_{2} \mathrm{O}$ per $\mathrm{kg}$ of FM. Silage treatments were designed as control, LAB, cellulase, and LAB+cellulase. The LAB and cellulase were diluted with deionized water, and the additive solution was sprayed using an electronic sprayer (SSP-5H, fujiwara Sangyo Co., Ltd, Miki, Japan) for addition of experiment treatments. The same amount of deionized water was sprayed on the control treatment.

\section{Microbial analysis}

The counts of microorganisms in the crop by-products or silages were measured by the plate count method [11]. Samples $(10 \mathrm{~g})$ were blended with $90 \mathrm{ml}$ sterilized water and serially diluted $10^{-1}$ to $10^{-8}$ in sterilized water. The numbers of LAB were measured on Lactobacilli MRS (de Man, Rogosa and Sharpe) agar (Difco Laboratories, Detroit, MI, USA) incubated at $30^{\circ} \mathrm{C}$ for $48 \mathrm{~h}$ under anaerobic conditions (Anaerobic Pack Rectangular Jar; 2.5 liters, Mitsubushi Gas Chemical Company INC, Tokyo, Japan). For isolation of LAB, more than 20 strains on MRS agar medium were picked randomly from each sample, and a total of 97 isolates were collected, of which 75 isolates were considered to be $\mathrm{LAB}$, as determined by the Gram-stain appearance, catalase test and lactic acid productivity [11]. Aerobic bacteria were counted on Nutrient agar (Nissui-Seiyaku Co., Ltd, Tokyo, Japan) incubated for $48 \mathrm{~h}$ at $30^{\circ} \mathrm{C}$ under aerobic conditions. Coliform bacteria were counted on Blue Light agar (Nissui-Seiyaku, Japan) incubated at $30^{\circ} \mathrm{C}$ for $48 \mathrm{~h}$; mold and yeast were counted on Potato Dextrose agar (Nissui-Seiyaku, Japan) incubated for 48 to $72 \mathrm{~h}$ at $30^{\circ} \mathrm{C}$. Yeasts were distinguished from mold and bacteria by colony appearance and observation of cell morphology. Col- 
onies were counted as viable numbers of microorganisms in cfu/g of FM. For LAB identification, each colony of LAB was purified twice by streaking on a MRS agar plate. The pure cultures were grown on MRS agar at $30^{\circ} \mathrm{C}$ for $24 \mathrm{~h}$, resuspended in a solution of nutrient broth (Difco, USA) and dimethyl sulfoxide at a ratio of 9:1, and stored as stock cultures in a deep freezer (MDF-U384, Sanyo Electric Co., Ltd, Osaka, Japan) at $-80^{\circ} \mathrm{C}$ until further examination.

Gram stain and morphological characteristics of $\mathrm{LAB}$ were determined after $24 \mathrm{~h}$ of incubation on MRS agar, and their catalase activity and gas production from glucose were determined as described by Kozaki et al [11]. Growth at different temperatures was detected in MRS broth after incubation at $5^{\circ} \mathrm{C}$ and $10^{\circ} \mathrm{C}$ for $10 \mathrm{~d}$, and at $40^{\circ} \mathrm{C}, 45^{\circ} \mathrm{C}$, and $50^{\circ} \mathrm{C}$ for $7 \mathrm{~d}$. Growth at pH 3.0 to 7.0 was observed in MRS broth after incubation at $30^{\circ} \mathrm{C}$ for $7 \mathrm{~d}$. Carbohydrate assimilation and fermentation of 49 different compounds with one control were identified on AP $50 \mathrm{CH}$ strips. These strains were divided into five groups (A to E) according to morphological and biochemical characters and 16S rRNA sequence analysis, and the representative strains of each group were selected by their different fermentation patterns of AP $50 \mathrm{CH}$.

\section{$16 \mathrm{~S}$ rRNA gene sequence analysis}

Cells of representative strains grown for $8 \mathrm{~h}$ in MRS broth at $30^{\circ} \mathrm{C}$ were used for DNA extraction and purification [12]. The $16 \mathrm{~S}$ rDNA sequence coding region was amplified by polymerase chain reaction (PCR) and performed in a PCR ThermalCycler (GenAmp PCR System 9700; PE Applied Biosystems, Foster City, CA, USA) and reagents from a Takara Taq PCR Kit (Takara Shuzo Co., Ltd, Otsu, Japan). Sequencing was performed twice on both strands by the dideoxy method using a PRISM BigDye Terminator Cycle Sequence Ready Reaction Kit (Applied Biosystems, USA) in combination with an Applied Biosystems model 310 A automated sequencing system. Searching $16 \mathrm{~S}$ rDNA sequence similarity was performed at GenBank data library by using the BLAST program. Then the sequence information was introduced into the CLUSTAL W software program (Hitachi Software Engineering Co., Ltd, Tokyo, Japan) for assembly and alignment [13]. The 16S rDNA sequences of isolates were compared with sequences from the strains of LAB held in the GenBank. Nucleotide substitution rates were calculated, and phylogenetic trees were constructed by the neighbor-joining method. Bacillus subtilis NCDO 1769 was used as an outgroup organism [11]. The topology of trees was evaluated by bootstrap analysis of the sequence data with CLUSTAL W software based on 100 random resamplings [13].

\section{Chemical analysis}

Pre-ensiled corn stover and sugarcane tops, and their silage samples were dried in a forced air oven at $70^{\circ} \mathrm{C}$ for $48 \mathrm{~h}$, and ground to pass a $1 \mathrm{~mm}$ mesh screen (FW 100, Taisite Instrument Co., Ltd, Tianjin, China) for chemical composition analyses. The data of chemical composition on DM basis were corrected for residual moisture after $3 \mathrm{~h}$ at $105^{\circ} \mathrm{C}$. The $\mathrm{DM}$, ash, crude protein $(\mathrm{CP})$ and ether extract (EE) were analyzed by the methods $934.01,942.05,976.05$, and 920.39 of AOAC [14], respectively. The organic matter (OM) content was calculated as the weight loss upon ashing. The neutral detergent fiber (NDF) and acid detergent fiber (ADF) were obtained according to the method of Van Soest et al [15] with an ANKOM A200i fiber analyzer (ANKOM Technology, Macedon, NY, USA) and were expressed exclusive of residual ash. The acid detergent lignin (ADL) analysis was subsequently performed following the procedure of Van Soest et al [15]. The WSC was determined by Anthron method [16]. Lactate buffer capacity (LBC) was measured by titrating with $0.1 \mathrm{M}$ $\mathrm{HCl}$ to reduce $\mathrm{pH}$ from initial $\mathrm{pH}$ to $\mathrm{pH} 3.0$ and then titrated to $\mathrm{pH} 6.0$ with $0.1 \mathrm{M} \mathrm{NaOH}$ as described by McDonald et al [17]. Degradable intake protein (DIP) was analyzed by the method of Roe et al [18]. Undegraded intake protein (UIP) was calculated as described by Licitra et al [19]. Soluble intake protein (SIP) was analyzed by the method of Licitra et al [19] in omitting sodium azide. Binding protein (BP) and neutral detergent insoluble protein (NDIP), the CP contents of sequential NDF residue were determined with the method of Licitra et al [19]. Pre-ensiled material and samples preparation for macro mineral analysis was carried out as described by Khan et al [20]. The concentration of calcium $(\mathrm{Ca})$, phosphorous $(\mathrm{P})$, magnesium $(\mathrm{Mg})$, and potassium $(\mathrm{K})$ was measured using an atomic absorption spectrophotometer (PerkinElmer, LAMBDA 1050, Shelton, CT, USA).

\section{Fermentation analysis}

The fermentation products of silage were analyzed by using cold-water extract, a $10 \mathrm{~g}$ wet silage sample was homogenized with $90 \mathrm{~mL}$ of deionized water and kept in a refrigerator at $4^{\circ} \mathrm{C}$ for $24 \mathrm{~h}$ as described by Cai [10]. Then, the material was filtered, and the filtrate was used to measure $\mathrm{pH}$, ammonia$\mathrm{N}$, and organic acids. The $\mathrm{pH}$ was measured using a glass electrode $\mathrm{pH}$ meter (Starter 100/B, OHAUS, Shanghai, China), the ammonia-N content was analyzed by using steam distillation of the filtrates [10], the concentration of organic acid including lactic acid, acetic acid, propionic acid and butyric acid were measured by high-performance liquid chromatography (Sodex RS Pak KC-811column; Showa Denko K.K., Kawasaki, Japan; DAD detector: $210 \mathrm{~nm}$, SPD-20A, Shimadzu Co. Ltd., Kyoto, Japan; eluent: $3 \mathrm{~mm} \mathrm{HClO} 4,1.0 \mathrm{~mL} / \mathrm{min}$; temperature: $40^{\circ} \mathrm{C}$ ) methods as described by Cai [10].

\section{Statistical analysis}

Data on the microorganism population, chemical composition and fermentation quality after $60 \mathrm{~d}$ of ensiling were 
analyzed with a completely randomized design with a $2 \times 4$ (crops [C] $\times$ additives $[\mathrm{A}]$ ) factorial treatment structure. The two ways analysis of variance (ANOVA) procedure of SAS version 9.1 (SAS Institute, Cary, NC, USA) was used for the analysis and the statistical model is as follows:

$$
Y_{i j k}=\mu+\alpha_{i}+\beta_{j}+\alpha \beta_{i j}+\varepsilon_{i j k}
$$

where $\mathrm{Y}_{\mathrm{ijk}}=$ observation; $\mu$ = overall mean, $\alpha_{\mathrm{i}}=$ crops effect $(\mathrm{i}$ $=$ corn stover and sugarcane top), $\beta_{j}=$ additives effect $(j=1$ to 4$), \alpha \beta_{\mathrm{ij}}=$ crops $\times$ additives effect, and $\varepsilon_{\mathrm{ijk}}=$ error. The mean values were compared by Tukey's test [21].

\section{Accession numbers}

The nucleotide sequences for the $16 \mathrm{~S}$ rDNA described in this report were deposited with GenBank under accession numbers LC434015, LC434016, LC434017, LC434018, and LC434019 for the strains MB1, MB14, MB6, MB52, and MB38, respectively.

\section{RESULTS}

The chemical, protein and macro mineral composition of corn stover and sugarcane tops are shown in Table 1. The DM content of the fresh corn stover was $16.97 \%$ higher $(p<0.05)$ than that in fresh sugarcane tops. The CP and EE contents of both crop by-products did not show marked differences. The OM, NDF, ADF, ADL, and LBC contents of corn stover were lower $(p<0.05)$ than those of respective values in sugarcane tops. The WSC content of corn stover was $2.53 \%$ of DM higher $(\mathrm{p}<0.05)$ than sugarcane tops. Regarding the protein composition, the DIP and SIP contents were higher $(\mathrm{p}<0.05)$, and the UIP and NDIP contents lower $(\mathrm{p}<0.05)$, in the corn stover than in sugarcane tops. The BP contents were similar in both crops. Regarding the macro minerals, the $\mathrm{K}$ contents were similar in both crops, while the $\mathrm{Ca}$, $\mathrm{P}$, and $\mathrm{Mg}$ contents were higher $(\mathrm{p}<0.05)$ in the corn stover.

The microbial population of the corn stover and sugarcane tops before ensiling are shown in Table 2. Aerobic bacteria dominated both crops with similar levels of $10^{7} \mathrm{cfu} / \mathrm{g}$ in FM. The corn stover contained $10^{7}$ coliform bacteria, $10^{6}$ yeasts, and $10^{4}$ molds cfu/g in FM. The microbial counts for all three microorganisms were lower in the sugarcane tops than corn stover. The natural LAB, including the genera Lactobacillus, Weissella, Lactococcus, and Pediococcus, were present at $10^{3}$ to $10^{6} \mathrm{cfu} / \mathrm{g}$ of FM in both crops.

The characteristics of LAB of corn stover and sugarcane tops and their silages are shown in Table 3. Representative strains MB1, MB6, MB14, MB38, and MB52 were isolated from both crops or their silages. A total of 97 strains were isolated from MRS agar plates. Of those, 22 strains did not exhibit characteristics of LAB, namely Gram-negative, cata-

Table 1. Chemical, protein and macro mineral composition of corn stover and sugarcane tops

\begin{tabular}{|c|c|c|c|c|}
\hline Items & Corn stover & Sugarcane top & SEM & $\mathrm{p}$-value \\
\hline \multicolumn{5}{|l|}{ Chemical composition } \\
\hline $\mathrm{DM}(\%)$ & $42.65 \pm 1.67^{\mathrm{a}}$ & $25.68 \pm 2.08^{b}$ & 1.09 & 0.0004 \\
\hline $\mathrm{CP}(\%$ of $\mathrm{DM})$ & $6.52 \pm 0.20$ & $6.77 \pm 0.78$ & 0.33 & 0.6165 \\
\hline $\mathrm{EE}(\%$ of $\mathrm{DM})$ & $1.57 \pm 0.60$ & $1.80 \pm 0.28$ & 0.30 & 0.6319 \\
\hline NDF ( $\%$ of DM) & $65.05 \pm 0.50^{b}$ & $76.10 \pm 2.01^{\mathrm{a}}$ & 0.85 & 0.0008 \\
\hline WSC ( $\%$ of DM) & $10.38 \pm 0.40^{a}$ & $7.85 \pm 0.39^{b}$ & 0.23 & 0.0014 \\
\hline LBC (meq/ kg of DM) & $539.75 \pm 21.23^{b}$ & $1,772.40 \pm 183.30^{\mathrm{a}}$ & 75.33 & 0.0003 \\
\hline \multicolumn{5}{|c|}{ Protein composition (\% of CP) } \\
\hline DIP & $69.34 \pm 1.51^{\mathrm{a}}$ & $61.36 \pm 2.08^{b}$ & 1.05 & 0.0051 \\
\hline UIP & $30.66 \pm 1.75^{b}$ & $38.64 \pm 1.40^{\mathrm{a}}$ & 0.92 & 0.0034 \\
\hline \multicolumn{5}{|l|}{ Macro mineral (mg/kg) } \\
\hline $\mathrm{Ca}$ & $0.35 \pm 0.01^{\mathrm{a}}$ & $0.27 \pm 0.04^{b}$ & 0.01 & 0.0177 \\
\hline$P$ & $0.20 \pm 0.01^{\mathrm{a}}$ & $0.14 \pm 0.01^{b}$ & 0.01 & 0.0031 \\
\hline $\mathrm{Mg}$ & $0.21 \pm 0.01^{\mathrm{a}}$ & $0.18 \pm 0.01^{b}$ & 0.01 & 0.0161 \\
\hline
\end{tabular}

SEM, standard error of the mean; DM, dry matter; OM, organic matter; $C P$, crude protein; $E E$, ether extract; NDF, neutral detergent fiber; $A D F$, acid detergent fiber; $A D L$, acid detergent lignin; WSC, water soluble carbohydrates; LBC, lactate buffer capacity; DIP, degradable intake protein; UIP, undegradable intake protein; SIP, soluble intake protein; $\mathrm{BP}$, binding protein; NDIP, neutral detergent insoluble protein; Ca, calcium; $\mathrm{P}$, phosphorous; Mg, magnesium; $\mathrm{K}$, potassium.

$a, b$ Means \pm standard deviation within rows with different superscript letters differ significantly from each other $(p<0.05)$. 
Table 2. Microbial population of corn stover and sugarcane tops before ensiling

\begin{tabular}{|c|c|c|c|c|c|c|c|c|c|}
\hline \multirow{2}{*}{ Items } & $\begin{array}{c}\text { Lactic acid } \\
\text { bacteria }\end{array}$ & Lactobacilli & Weissella & Lactococci & Pediococci & $\begin{array}{c}\text { Aerobic } \\
\text { bacteria }\end{array}$ & $\begin{array}{l}\text { Coliform } \\
\text { bacteria }\end{array}$ & Yeasts & Molds \\
\hline & \multicolumn{9}{|c|}{ - } \\
\hline Corn stover & 5.73 & 5.70 & 3.18 & 3.75 & ND & 7.89 & 7.72 & 6.41 & 4.12 \\
\hline Sugarcane top & 6.56 & 3.08 & 6.54 & ND & 3.87 & 7.20 & 5.26 & 4.27 & 3.79 \\
\hline
\end{tabular}

Data are means of three samples.

cfu, colony-forming unit; FM, fresh matter; ND, not detected.

lase-positive, and unable to produce lactic acid in MRS broth. The other 75 strains were considered to be LAB, they were Gram-positive and catalase-negative rods or cocci. Those strains are able to form $\mathrm{D}(-)$ isomer, $\mathrm{L}(+)$ isomer, or approximately equal quantities of $\mathrm{D}(-)$ and $\mathrm{L}(+)$-lactic acid, and did or did not produce gas from glucose.

The phylogenetic trees of $16 \mathrm{~S}$ rRNA gene sequence for rodshaped and cocci-shaped LAB strains obtained in this study are shown in Figure 1, 2, respectively. More than 1,500 bases of $16 \mathrm{~S}$ rRNA of these strains were determined. Following phylogenetic analysis, the rod-shaped strains MB1, FG, and
MB14 were placed in the cluster making up the genus Lactobacillus. Strains MB14 were clearly assigned to the Lactobacillus brevis. While strains MB1 and FG grouped on the phylogenetic tree together with $L$. plantarum, including species, $L$. pentosus, $L$. argentoratensis, and L. paraplantarum, and in a $100 \%$ bootstrap cluster. Furthermore, strains MB1 and FG appeared to be equally linked to $L$. plantarum, these strains were phylogenetically associated with $L$. plantarum. Coccishaped strains MB6, MB38, and MB52 were placed in the cluster making up the genus Weissella, Lactococcus, and Pediococcus, respectively. These type strains of Weissella ci-

Table 3. Characteristics of lactic acid bacteria isolated from corn stover, sugarcane tops and inoculant

\begin{tabular}{|c|c|c|c|c|c|c|}
\hline Characteristic & $\begin{array}{l}\text { Lactobacillus } \\
\text { plantarum }\end{array}$ & $\begin{array}{c}\text { Lactobacillus } \\
\text { brevis }\end{array}$ & $\begin{array}{c}\text { Weissella } \\
\text { cibaria }\end{array}$ & $\begin{array}{l}\text { Lactococcus } \\
\text { lactlis }\end{array}$ & $\begin{array}{l}\text { Pediococcus } \\
\text { acidilactici }\end{array}$ & $\begin{array}{c}\text { Lactobacillus } \\
\text { plantarum }\end{array}$ \\
\hline Representative strain & MB1 & MB14 & MB6 & MB52 & MB38 & FG \\
\hline Isolated source & Corn stover & Sugarcane tops & Corn stover & Sugarcane tops & Corn stover & Inoculant \\
\hline Shape & Rod & Rod & Cocci & Cocci & Cocci & Rod \\
\hline Gram stain & + & + & + & + & + & + \\
\hline Catalase & - & - & - & - & - & - \\
\hline Gas from glucose & - & + & + & - & - & - \\
\hline Lactate production in MRS broth (\%) & 1.96 & 1.31 & 0.67 & 0.45 & 0.92 & 0.92 \\
\hline Final pH in MRS broth & 3.50 & 3.85 & 4.40 & 4.60 & 4.20 & 4.20 \\
\hline Fermentation type & Homo & Hetero & Hetero & Homo & Homo & Homo \\
\hline Optical form of lactate & $D L$ & $\mathrm{DL}$ & D(-) & $\mathrm{L}(+)$ & DL & $\mathrm{DL}$ \\
\hline \multicolumn{7}{|l|}{ Growth at pH } \\
\hline 3.0 & - & - & - & - & - & - \\
\hline 3.5 & + & - & - & - & - & - \\
\hline 4.0 & + & + & w & - & - & - \\
\hline 4.5 & + & + & + & w & + & + \\
\hline 5.0 & + & + & + & + & + & + \\
\hline \multicolumn{7}{|l|}{ Carbohydrate fermentation patterns } \\
\hline L-Arabinose & + & + & w & - & + & + \\
\hline Ribose & + & + & - & + & + & + \\
\hline D-Xylose & - & + & w & + & + & - \\
\hline Galactose & + & - & - & + & + & + \\
\hline D-Mannose & + & - & + & + & + & + \\
\hline Mannitol & + & - & - & + & - & + \\
\hline a Methyl-D-mannoside & + & - & - & - & - & + \\
\hline Amygdaline & + & - & + & + & + & + \\
\hline $16 \mathrm{~S}$ rDNA similarity with each type strain (\%) & 100.00 & 99.80 & 99.90 & 99.80 & 99.90 & 99.90 \\
\hline
\end{tabular}

+ , positive; - negative; $w$, weakly positive.

Carbohydrate fermentation pattern was tested by AP $50 \mathrm{CH}$; the sequence similarity of $16 \mathrm{~S}$ rDNA of isolates were compared with sequences from each type strains of LAB held in the GenBank. 


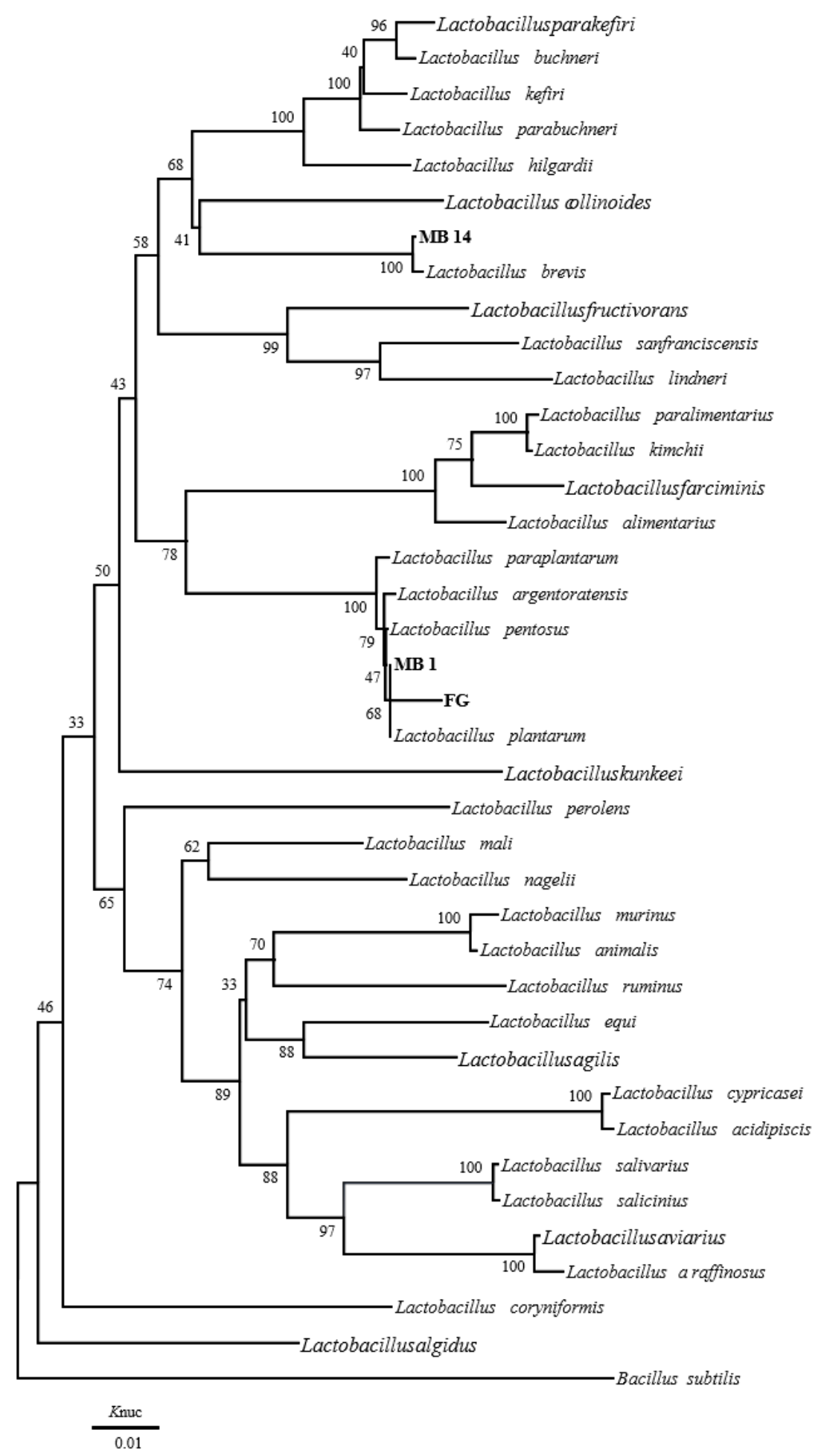

Figure 1. Phylogenetic tree showing the relationship between the 165 rDNA sequences of rod-shaped LAB strains obtained in this study. Numbers at nodes are bootstrap values based on a neighbor-joining bootstrap analysis with 1,000 replications. Bacillus subtilis is used as the outgroup. The bar indicates $1 \%$ sequence divergence. Knuc, nucleotide substitution rates; $L A B$, lactic acid bacteria.

baria, Lactococcus lactis, and Pediococcus acidilactici were the species most closely to the strains MB6, MB38, and MB52 in the phylogenetic tree, and they showed the sequence similarity value more than $99.80 \%$ with each strain. Based on the morphological and biochemical characteristics, and $16 \mathrm{~S}$ rRNA gene sequence analysis, these isolates were identified as Lactobacillus plantarum, Lactobacillus brevis, Weissella cibaria, Lactococcus lactis, and Pediococcus acidilactici. 


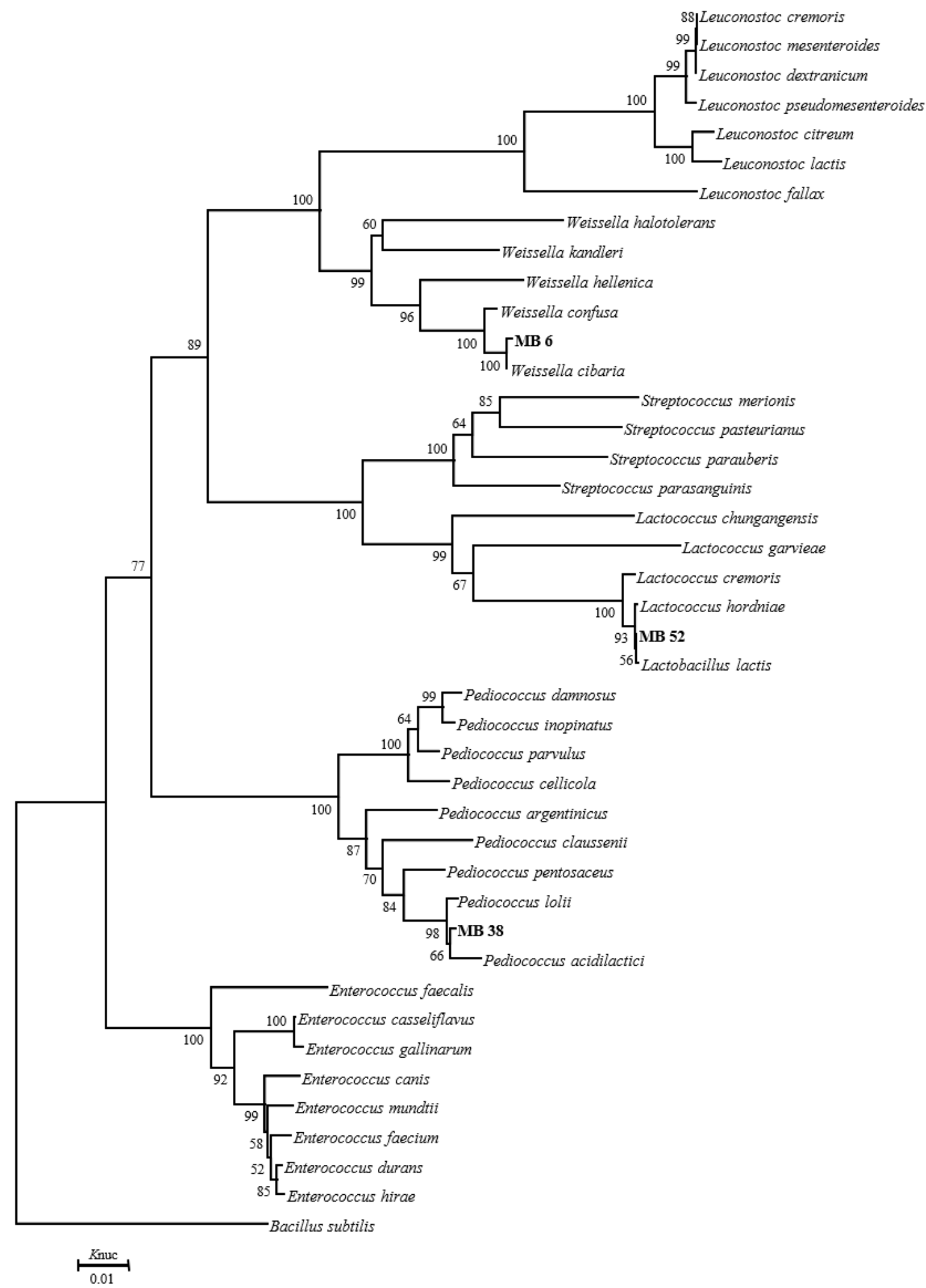

Figure 2. Phylogenetic tree showing the relationship between the $16 \mathrm{~S}$ rDNA sequences of cocci-shaped LAB strains obtained in this study. Numbers at nodes are bootstrap values based on a neighbor-joining bootstrap analysis with 1,000 replications. Baccillus subtilis is used as the outgroup. The bar indicates $1 \%$ sequence divergence. Knuc, nucleotide substitution rates; LAB, lactic acid bacteria.

The LAB community of corn stover and sugarcane tops and their silages are shown in Figure 3. Microbial diversity of $\mathrm{LAB}$ was observed in corn stover, where Lactobacillus plan- tarum (58.40\%; percentage of total isolates), Lactobacillus brevis (20.60\%), Weissella cibaria (17.00\%), and Pediococcus acidilactici (4.00\%) were the predominant species. In the 


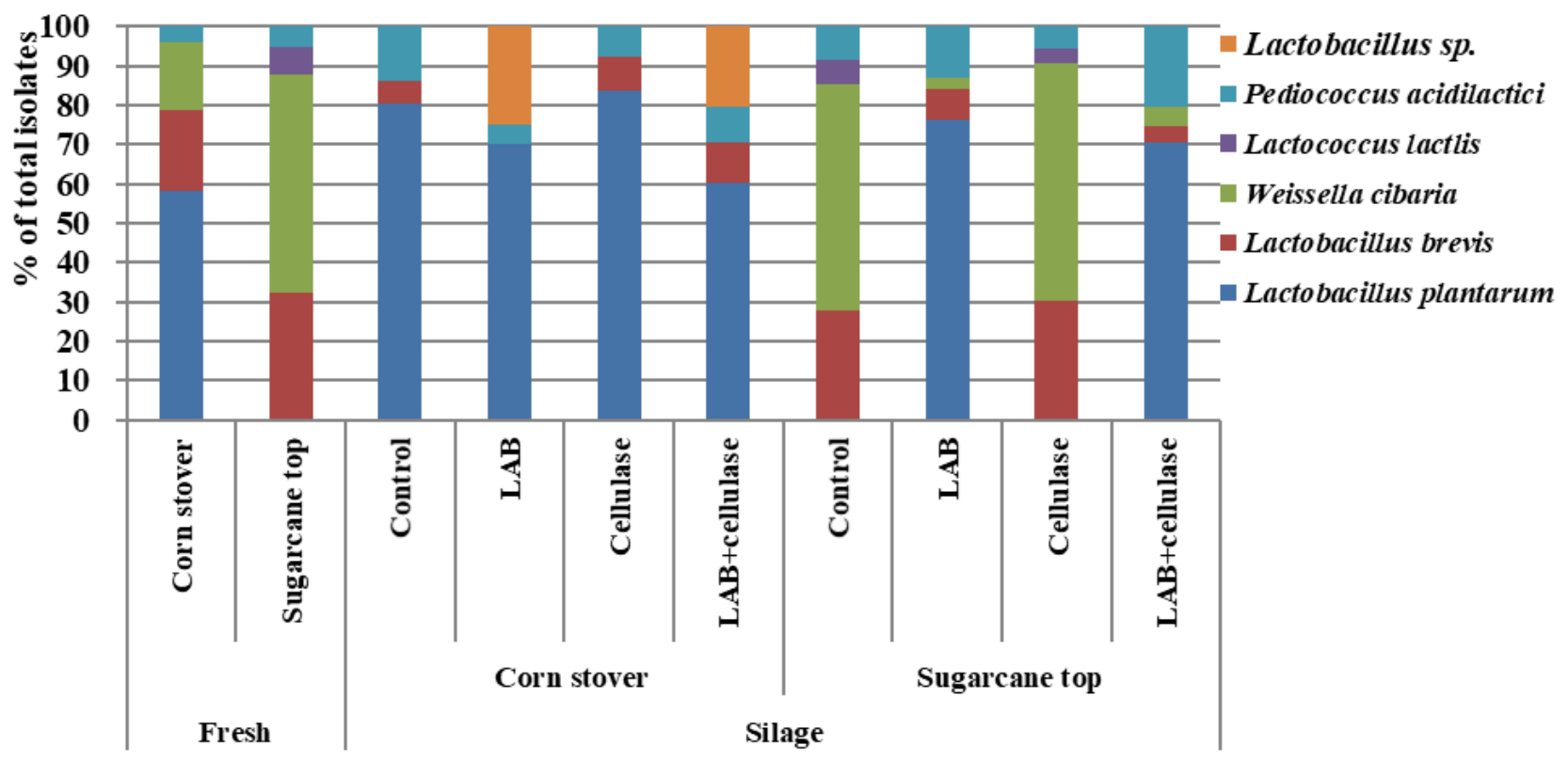

Figure 3. Community of lactic acid bacteria of corn stover, sugarcane top and silage. LAB, lactic acid bacteria inoculant FG; Cellulase, Acremonium cellulase.

sugarcane tops, the LAB microbial communities included Lactobacillus brevis (32.20\%), Weissella cibaria (55.60\%), Lactococcus latcis (7.20\%), and Pediococcus acidilactici (5.00\%). Lactobacillus plantarum, the dominant bacterium in the corn stover, was not detected in the sugarcane tops. Weissela cibaria was the dominant LAB in sugarcane tops. Lactobacillus brevis and Pediococcus acidilactici were abundant in both crops. After $60 \mathrm{~d}$ of fermentation, $L$. plantarum was the dominant LAB species $(76.30 \%$ to $83.60 \%$ of total isolates) in the LAB- and LAB+celllulase-treated sugarcane tops, and all corn stover silages, while Weissella cibaria $(57.40 \%$ to $60.50 \%)$ was the dominant species in control and cellulase-treated sugarcane top silages.

The chemical composition of corn stover and sugarcane top silages are shown in Table 4 . After $60 \mathrm{~d}$ of ensiling, the $\mathrm{CP}$ contents of the corn stover and sugarcane tops silages were similar, ranging from $5.99 \%$ to $6.57 \%$ and $6.00 \%$ to $6.28 \%$ of $\mathrm{DM}$, respectively. The contents of OM and EE in by-product silages did not show marked differences from the control, $\mathrm{LAB}$, cellulase or combined $\mathrm{LAB}$ and cellulase treatments. However, the NDF and ADF contents of the cellulase-treated silages were lower $(p<0.05)$ than those of control and LABtreated silages. Compared to corn stover silages, the OM, EE, $\mathrm{NDF}, \mathrm{ADF}$, and ADL contents of sugarcane tops silages were higher $(\mathrm{p}<0.05)$. Crops $(\mathrm{C})$ influenced $\mathrm{OM}, \mathrm{EE}, \mathrm{NDF}, \mathrm{ADF}$, and ADL contents ( $\mathrm{p}=0.0073$ to 0.0164 or $\mathrm{p}<0.0001$ ), but the $\mathrm{CP}(\mathrm{p}=0.3059)$ did not. The additives (A) influenced $(\mathrm{p} \leq$ $0.0001) \mathrm{NDF}$ and ADF contents, while the other chemical composition did not ( $p=0.2580$ to 0.6179$)$. The interaction between $\mathrm{C}$ and $\mathrm{A}(\mathrm{C} \times \mathrm{A})$ influenced $(\mathrm{p}=0.0344$ to 0.0445$)$ $\mathrm{NDF}$ and $\mathrm{ADL}$ contents, but not $\mathrm{OM}, \mathrm{CP}, \mathrm{EE}$, or $\mathrm{ADF}(\mathrm{p}=$
0.2932 to 0.9777$)$.

The fermentation quality of the corn stover and sugarcane top silages after $60 \mathrm{~d}$ of fermentation is shown in Table 5 . All of the corn stover silages were well-preserved, with low $\mathrm{pH}$ values ( $<3.97)$ and ammonia- $\mathrm{N}$ content $(<0.77 \% \mathrm{~g} / \mathrm{kg}$ of $\mathrm{DM})$, and high lactic acid content $(>4.14 \%$ of $\mathrm{DM})$. The fermentation quality of the control, LAB-, cellulase-, and LAB+ cellulase-treated corn stover silages did not display marked differences. In contrast, the fermentation quality of sugarcane top silages varied markedly. After $60 \mathrm{~d}$ of fermentation, the control silage was of poor quality, with low lactic acid content ( $0.61 \%$ of $\mathrm{DM})$ and a relatively high $\mathrm{pH}$ value (4.71). However, the LAB-, cellulase-, and LAB+cellulase-treated silages had similar good fermentation patterns, with higher $(\mathrm{p}<0.05)$ lactic acid contents and lower $(\mathrm{p}<0.05) \mathrm{pH}$ than those of the control silage. The DM and lactic acid content were higher $(\mathrm{p}<0.05)$, and the $\mathrm{pH}$ and butyric acid content lower $(\mathrm{p}<0.05)$, in corn stover silages compared with sugarcane top silages. The acetic acid, propionic acid, and ammonia- $\mathrm{N}$ contents were similar between the corn stover and sugarcane top silages. The $\mathrm{C}$ influenced ( $\mathrm{p}=0.0005$ to 0.0088 or $\mathrm{p}<0.0001$ ) silage $\mathrm{DM}, \mathrm{pH}$, lactic acid, butyric acid and ammonia- $\mathrm{N}$ contents, while the $\mathrm{A}$ and $\mathrm{A} \times \mathrm{C}$ influenced $\mathrm{pH}$ ( $\mathrm{p}=0.0012$ to 0.0024 ), lactic acid ( $\mathrm{p}=0.0072$ to 0.0073 ), acetic acid ( $\mathrm{p}=0.0008$ to 0.0160 ), butyric acid ( $\mathrm{p}=0.0005$ to 0.0008 ) and ammonia$\mathrm{N}(\mathrm{p}=0.0071$ to 0.0111$)$. The A also influenced $(\mathrm{p}=0.0434)$ the propionic acid content.

The microbial populations of corn stover and sugarcane top silages after $60 \mathrm{~d}$ of fermentation are shown in Table 6 . For the corn stover silages, the microbial populations were similar among all treatments; $\mathrm{LAB}\left(10^{6} \mathrm{cfu} / \mathrm{g}\right.$ of FM $)$ was the 
Table 4. Chemical composition of corn stover and sugarcane top silage after $60 \mathrm{~d}$ of fermentation

\begin{tabular}{|c|c|c|c|c|c|c|}
\hline \multirow{2}{*}{ Items } & $\mathrm{OM}$ & $\mathrm{CP}$ & $\mathrm{EE}$ & NDF & ADF & $A D L$ \\
\hline & \multicolumn{6}{|c|}{ 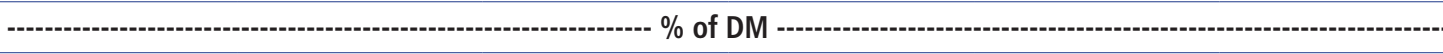 } \\
\hline \multicolumn{7}{|l|}{ Corn stover } \\
\hline Control & $91.98 \pm 5.38$ & $6.44 \pm 0.59$ & $1.28 \pm 0.27$ & $64.69 \pm 0.62^{\mathrm{a}}$ & $36.11 \pm 0.28^{a}$ & $2.95 \pm 0.35^{\mathrm{ab}}$ \\
\hline$\angle A B$ & $91.01 \pm 0.40$ & $5.99 \pm 0.10$ & $1.61 \pm 0.33$ & $64.54 \pm 0.54^{a}$ & $36.09 \pm 0.16^{a}$ & $3.26 \pm 0.98^{\mathrm{a}}$ \\
\hline Cellulase & $88.84 \pm 3.30$ & $6.57 \pm 0.45$ & $1.33 \pm 0.17$ & $59.67 \pm 1.04^{b}$ & $33.53 \pm 0.59^{b}$ & $2.05 \pm 0.41^{b}$ \\
\hline LAB+cellulase & $88.14 \pm 4.52$ & $6.53 \pm 0.94$ & $1.42 \pm 0.34$ & $60.49 \pm 0.79^{b}$ & $33.29 \pm 0.83^{b}$ & $2.27 \pm 0.25^{\mathrm{ab}}$ \\
\hline \multicolumn{7}{|l|}{ Sugarcane top } \\
\hline Control & $92.76 \pm 2.05$ & $6.21 \pm 0.83$ & $1.63 \pm 0.56$ & $77.89 \pm 1.58^{\mathrm{a}}$ & $46.22 \pm 0.97^{\mathrm{a}}$ & $4.05 \pm 0.53^{\mathrm{a}}$ \\
\hline$L A B$ & $94.70 \pm 1.22$ & $6.00 \pm 0.09$ & $1.95 \pm 0.15$ & $76.16 \pm 0.82^{\mathrm{ab}}$ & $44.80 \pm 1.67^{\mathrm{ab}}$ & $4.29 \pm 0.24^{\mathrm{a}}$ \\
\hline Cellulase & $93.25 \pm 0.66$ & $6.28 \pm 0.52$ & $1.83 \pm 0.62$ & $74.97 \pm 0.34^{b}$ & $43.34 \pm 1.27^{b}$ & $4.61 \pm 0.32^{\mathrm{a}}$ \\
\hline LAB+cellulase & $93.90 \pm 0.35$ & $6.05 \pm 0.37$ & $1.86 \pm 0.28$ & $74.79 \pm 1.78^{b}$ & $44.05 \pm 0.21^{\mathrm{ab}}$ & $4.22 \pm 0.12^{\mathrm{a}}$ \\
\hline SEM & 1.69 & 0.33 & 0.22 & 0.58 & 0.52 & 0.27 \\
\hline \multicolumn{7}{|l|}{ Forage means } \\
\hline Corn stover & $89.99 \pm 3.74^{b}$ & $6.38 \pm 0.57$ & $1.41 \pm 0.27^{b}$ & $62.35 \pm 2.48^{b}$ & $34.75 \pm 1.48^{b}$ & $2.63 \pm 0.71^{b}$ \\
\hline Sugarcane top & $93.65 \pm 1.31^{\mathrm{a}}$ & $6.14 \pm 0.46$ & $1.82 \pm 0.40^{\mathrm{a}}$ & $75.95 \pm 1.68^{\mathrm{a}}$ & $44.60 \pm 1.49^{a}$ & $4.29 \pm 0.36^{\mathrm{a}}$ \\
\hline \multicolumn{7}{|l|}{ Additive means } \\
\hline Control & $92.37 \pm 3.66$ & $6.32 \pm 0.65$ & $1.45 \pm 0.44$ & $71.29 \pm 7.31^{\mathrm{a}}$ & $41.16 \pm 5.57^{\mathrm{a}}$ & $3.50 \pm 0.72$ \\
\hline$L A B$ & $92.85 \pm 2.34$ & $6.00 \pm 0.09$ & $1.78 \pm 0.30$ & $70.35 \pm 6.39^{a}$ & $40.44 \pm 4.88^{\mathrm{a}}$ & $3.77 \pm 0.85$ \\
\hline Cellulase & $91.04 \pm 3.22$ & $6.42 \pm 0.46$ & $1.58 \pm 0.49$ & $67.32 \pm 8.41^{b}$ & $38.43 \pm 5.45^{b}$ & $3.33 \pm 1.44$ \\
\hline LAB+cellulase & $91.02 \pm 4.27$ & $6.29 \pm 0.69$ & $1.64 \pm 0.37$ & $67.64 \pm 7.93^{b}$ & $38.67 \pm 5.92^{b}$ & $3.24 \pm 1.08$ \\
\hline \multicolumn{7}{|c|}{ Significance of main effects and interactions } \\
\hline Crops (C) & 0.0073 & 0.3059 & 0.0164 & $<0.0001$ & $<0.0001$ & $<0.0001$ \\
\hline Additives (A) & 0.6179 & 0.6037 & 0.5185 & $<0.0001$ & 0.0001 & 0.2580 \\
\hline$C \times A$ & 0.5234 & 0.8975 & 0.9777 & 0.0445 & 0.2932 & 0.0344 \\
\hline
\end{tabular}

Data are means of three silage samples.

$\mathrm{OM}$, organic matter; $C P$, crude protein; $E E$, ether extract; NDF, neutral detergent fiber; $A D F$, acid detergent fiber; $A D L$, acid detergent lignin; DM, dry matter; $L A B$, lactic acid bacteria inoculant FG; Cellulase, Acremonium cellulase; SEM, standard error of the mean.

${ }_{a, b}$ Means \pm standard deviation within columns with different superscript letters differ significantly from each other $(p<0.05)$.

dominant species. Additionally, the aerobic bacteria count was $10^{4}$ to $10^{5} \mathrm{cfu} / \mathrm{g}$, and that of yeasts was $10^{5} \mathrm{cfu} / \mathrm{g}$ of FM. Meanwhile, coliform bacteria and molds were below detectable levels $\left(<10^{2} \mathrm{cfu} / \mathrm{g}\right.$ of FM). For the sugarcane top silages, $10^{4}$ to $10^{7} \mathrm{LAB}, 10^{3}$ to $10^{5}$ aerobic bacteria, and $10^{3}$ to $10^{5}$ yeasts counts were presented in the silages. In the LAB-, cellulase- and $\mathrm{LAB}+$ cellulase-treated silages, the LAB count was significantly $(\mathrm{p}<0.05)$ higher than that of the control, while that of aerobic bacteria was significantly $(\mathrm{p}<0.05)$ lower. Similar to the corn stover silages, the counts of coliform bacteria and molds in all sugarcane top silages were below detectable levels $\left(<10^{2} \mathrm{cfu} / \mathrm{g}\right.$ of $\left.\mathrm{FM}\right)$. The $\mathrm{C}, \mathrm{A}$, and $\mathrm{C} \times \mathrm{A}$ influenced ( $\mathrm{p}$ $=0.0002$ to 0.0213 or $\mathrm{p}<0.0001)$ the $\mathrm{LAB}$, aerobic bacteria, and yeast counts.

\section{DISCUSSION}

In general, the chemical compositions of tropical grasses and forage crops were different, especially with regard to DM, CP, $\mathrm{NDF}$, and WSC contents. Some tropical grasses are less amenable to producing good-quality silage due to their low DM, high LBC, and low WSC contents [22]. The density is also an important factor for silage fermentation. In this study, the weight of corn and sugar cane silage packed into silo is 7.85 to $8.38 \mathrm{~kg}$. Although the moisture of the two kinds of silages is different, there is no large difference in density between the two silages. This may be because the top of the sugar cane is rich in leaf parts, while the corn stover is rich in stem parts. The CP and EE contents of the by-products of both crop types were at similar levels, but the corn stover exhibited more suitable ensiling characteristics, such as lower moisture content and LBC, and higher WSC content. In addition, the DIP, SIP, UIP, BP, NDIP, Ca, P, and Mg contents in the corn stover were much higher than those in sugarcane tops, suggesting that corn stover contains high amounts of digestible feed ingredients that could contribute to livestock feed.

To comprehensively understand the microbial populations in crop by-products and their silages, we investigated the abundance of four kinds of microbes: LAB, aerobic bacteria, molds, and yeasts. Generally, farm silage is based on natural lactic acid fermentation, and epiphytic LAB from forage transform the WSC into organic acids during the ensiling process. As a result, the $\mathrm{pH}$ is reduced and the forage preserved [23]. Therefore, the abundance, taxonomy, and 
Table 5. Fermentation quality of corn stover and sugarcane top silage after $60 \mathrm{~d}$ of fermentation

\begin{tabular}{|c|c|c|c|c|c|c|c|}
\hline \multirow{2}{*}{ Items } & \multirow{2}{*}{ DM \% } & \multirow{2}{*}{$\mathrm{pH}$} & Lactic acid & Acetic acid & Propionic acid & Butyric acid & \multirow{2}{*}{$\begin{array}{l}\text { Ammonia-N } \\
\text { (g/kg of DM) }\end{array}$} \\
\hline & & & \multicolumn{4}{|c|}{ 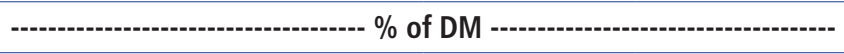 } & \\
\hline \multicolumn{8}{|l|}{ Corn stover } \\
\hline Control & $31.69 \pm 3.05$ & $3.93 \pm 0.13^{\mathrm{a}}$ & $5.00 \pm 0.91^{\mathrm{a}}$ & $1.19 \pm 0.21^{\mathrm{a}}$ & $0.04 \pm 0.03^{\mathrm{a}}$ & $0.01 \pm 0.01^{b}$ & $0.68 \pm 0.14$ \\
\hline$\angle A B$ & $31.07 \pm 1.78$ & $3.95 \pm 0.22^{a}$ & $5.14 \pm 1.56^{\mathrm{a}}$ & $1.06 \pm 0.16^{a}$ & $0.06 \pm 0.03^{\mathrm{a}}$ & $0.03 \pm 0.04^{b}$ & $0.59 \pm 0.09$ \\
\hline Cellulase & $31.02 \pm 1.29$ & $3.95 \pm 0.07^{\mathrm{a}}$ & $4.87 \pm 0.74^{a}$ & $1.17 \pm 0.12^{\mathrm{a}}$ & $0.09 \pm 0.05^{\mathrm{a}}$ & $0.12 \pm 0.05^{\mathrm{a}}$ & $0.77 \pm 0.15$ \\
\hline LAB+cellulase & $33.19 \pm 2.00$ & $3.97 \pm 0.12^{\mathrm{a}}$ & $4.14 \pm 0.62^{\mathrm{a}}$ & $1.10 \pm 0.11^{\mathrm{a}}$ & $0.02 \pm 0.01^{\mathrm{a}}$ & $0.11 \pm 0.03^{\mathrm{a}}$ & $0.76 \pm 0.14$ \\
\hline \multicolumn{8}{|l|}{ Sugarcane top } \\
\hline Control & $27.33 \pm 2.67$ & $4.71 \pm 0.08^{\mathrm{a}}$ & $0.61 \pm 0.30^{b}$ & $1.58 \pm 0.14^{a}$ & $0.10 \pm 0.02^{\mathrm{a}}$ & $2.49 \pm 0.79^{a}$ & $1.11 \pm 0.11$ \\
\hline$L A B$ & $27.71 \pm 0.04$ & $3.86 \pm 0.08^{b}$ & $4.82 \pm 0.41^{\mathrm{a}}$ & $0.77 \pm 0.17^{c}$ & $0.05 \pm 0.01^{b}$ & $0.46 \pm 0.23^{b}$ & $0.67 \pm 0.07$ \\
\hline Cellulase & $25.51 \pm 0.41$ & $4.09 \pm 0.32^{b}$ & $3.72 \pm 1.57^{\mathrm{a}}$ & $1.43 \pm 0.15^{\mathrm{ab}}$ & $0.09 \pm 0.04^{\mathrm{ab}}$ & $0.81 \pm 0.50^{b}$ & $0.83 \pm 0.10$ \\
\hline LAB+cellulase & $27.73 \pm 1.20$ & $4.06 \pm 0.05^{b}$ & $3.30 \pm 0.42^{\mathrm{a}}$ & $1.17 \pm 0.22^{b}$ & $0.06 \pm 0.01^{\mathrm{ab}}$ & $0.96 \pm 0.23^{b}$ & $0.73 \pm 0.07$ \\
\hline SEM & 1.06 & 0.09 & 0.54 & 0.10 & 0.02 & 0.20 & 0.06 \\
\hline \multicolumn{8}{|l|}{ Crop means } \\
\hline Corn stover & $31.74 \pm 2.03^{\mathrm{a}}$ & $3.95 \pm 0.12^{b}$ & $4.79 \pm 0.96^{\mathrm{a}}$ & $1.13 \pm 0.14$ & $0.05 \pm 0.04$ & $0.07 \pm 0.06^{b}$ & $0.70 \pm 0.13$ \\
\hline Sugarcane top & $27.07 \pm 1.58^{b}$ & $4.18 \pm 0.37^{\mathrm{a}}$ & $3.11 \pm 1.77^{b}$ & $1.24 \pm 0.35$ & $0.08 \pm 0.03$ & $1.18 \pm 0.92^{\mathrm{a}}$ & $0.84 \pm 0.19$ \\
\hline \multicolumn{8}{|l|}{ Additive means } \\
\hline Control & $29.51 \pm 3.50$ & $4.32 \pm 0.44^{\mathrm{a}}$ & $2.80 \pm 0.48^{c}$ & $1.39 \pm 0.26^{\mathrm{a}}$ & $0.07 \pm 0.04^{\mathrm{ab}}$ & $1.25 \pm 0.45^{\mathrm{a}}$ & $0.90 \pm 0.26$ \\
\hline$L A B$ & $29.39 \pm 2.16$ & $3.91 \pm 0.16^{b}$ & $4.98 \pm 1.03^{\mathrm{a}}$ & $0.92 \pm 0.21^{c}$ & $0.05 \pm 0.02^{\mathrm{ab}}$ & $0.24 \pm 0.28^{b}$ & $0.63 \pm 0.08$ \\
\hline Cellulase & $28.27 \pm 3.14$ & $4.02 \pm 0.22^{b}$ & $4.30 \pm 1.26^{\mathrm{ab}}$ & $1.30 \pm 0.19^{\mathrm{ab}}$ & $0.09 \pm 0.04^{\mathrm{a}}$ & $0.46 \pm 0.12^{b}$ & $0.80 \pm 0.12$ \\
\hline LAB+cellulase & $30.46 \pm 3.33$ & $4.01 \pm 0.10^{b}$ & $3.72 \pm 0.66^{\mathrm{bc}}$ & $1.14 \pm 0.16^{b}$ & $0.04 \pm 0.03^{b}$ & $0.54 \pm 0.49^{b}$ & $0.75 \pm 0.10$ \\
\hline \multicolumn{8}{|c|}{ Significance of main effects and interactions } \\
\hline Crops (C) & $<0.0001$ & 0.0027 & 0.0005 & 0.1258 & 0.0664 & $<0.0001$ & 0.0088 \\
\hline Additives (A) & 0.2679 & 0.0024 & 0.0073 & 0.0008 & 0.0434 & 0.0008 & 0.0071 \\
\hline $\mathrm{C} \times \mathrm{A}$ & 0.7099 & 0.0012 & 0.0072 & 0.0160 & 0.2706 & 0.0005 & 0.0111 \\
\hline
\end{tabular}

Data are means of three silage samples.

DM, dry matter; LAB, lactic acid bacteria inoculant FG; Cellulase, Acremonium cellulase; SEM, standard error of the mean.

${ }^{a-c}$ Means \pm standard deviation within columns with different superscript letters differ significantly from each other $(p<0.05)$.

characteristics of epiphytic LAB have become significant factors for predicting the adequacy of silage fermentation and determining whether to apply bacterial inoculants to silage materials [23]. When $\mathrm{LAB}$ are present in low numbers in forage crops or grasses, they will fail to produce sufficient lactic acid during fermentation to reduce the $\mathrm{pH}$ and inhibit the growth of clostridia; therefore, the resulting silage will be of poor quality. In this study, the microbial population between the two crops is different. The reason for this is unclear. Perhaps the cultivation environment and their chemical composition of both crops, especially moisture and WSC contents may influence the distribution of native microorganisms [24]. Relatively high numbers of $\mathrm{LAB}\left(>10^{5} \mathrm{cfu} / \mathrm{g}\right.$ of FM) were present in the corn stover in this study. In particular, Lactobacilli were dominant within the LAB populations. In this case, it would not be necessary to use bacterial inoculants to control contaminating microbes during silage fermentation (Table 1). However, very low numbers of LAB $\left(<10^{3} \mathrm{cfu} / \mathrm{g}\right.$ of FM) were observed in sugarcane tops, and Weissella were the dominant species in those populations; this suggests that it is necessary to use LAB inoculant to improve silage fermentation.

The isolates from this study were Gram-positive and cata- lase-negative rods or cocci that produced lactic acid from glucose. These properties suggest that these strains belong to the LAB species. The representative strains exhibited differences in terms of gas production from glucose, yielding approximately equal quantities of $\mathrm{L}(+)$ and $\mathrm{D}(-)$-lactic acid, but they could not be identified down to the species level on the basis of these phenotypic characteristics. The identification and genetic interrelationships of the LAB, including new species isolated from silage, have been studied extensively in $16 \mathrm{~S}$ rRNA gene sequence and DNA-DNA hybridisation experiments [23]. Recent results indicate that the LAB genera Lactobacillus, Pediococcus, Leuconostoc, Weissella, and Lactococcus exhibit a high degree of sequence similarity to one another and form a phylogenetically coherent group that is separate from other bacteria [1]. In the present study, isolated strains were of the genera Lactobacillus (two strains), Weissella, Lactococcus, and Pediococcus based on the phylogenetic analysis, thus confirming that these strains belong to these $\mathrm{LAB}$ genera. The representative strains MB1, MB6, MB14, MB38, and MB52 are the species most closely related to type strains of Lactobacillus plantarum, Lactobacillus brevis, Weissella cibaria, Lactococcus lactis, and Pediococcus acidilactici, respectively. The $16 \mathrm{~S}$ rDNA sequence similarity of 
Table 6. Microbial population of corn stover and sugarcane top silage after $60 \mathrm{~d}$ of fermentation

\begin{tabular}{|c|c|c|c|c|c|}
\hline \multirow{2}{*}{ Item } & Lactic acid bacteria & Aerobic bacteria & Coliform bacteria & Yeasts & Molds \\
\hline & \multicolumn{5}{|c|}{ - } \\
\hline \multicolumn{6}{|l|}{ Corn stover } \\
\hline Control & $6.31 \pm 0.72^{a}$ & $5.02 \pm 0.74^{a}$ & ND & $5.44 \pm 0.58^{a}$ & ND \\
\hline$L A B$ & $6.41 \pm 0.40^{\mathrm{a}}$ & $4.33 \pm 0.47^{\mathrm{a}}$ & ND & $5.57 \pm 0.20^{a}$ & ND \\
\hline Cellulase & $6.43 \pm 0.43^{\mathrm{a}}$ & $5.31 \pm 0.87^{\mathrm{a}}$ & ND & $5.30 \pm 0.42^{\mathrm{a}}$ & ND \\
\hline LAB+cellulase & $6.52 \pm 0.20^{\mathrm{a}}$ & $4.90 \pm 0.52^{\mathrm{a}}$ & ND & $5.54 \pm 0.24^{\mathrm{a}}$ & ND \\
\hline \multicolumn{6}{|l|}{ Sugarcane top } \\
\hline Control & $4.33 \pm 0.39^{d}$ & $5.48 \pm 0.33^{\mathrm{a}}$ & ND & $4.23 \pm 0.56^{a}$ & ND \\
\hline$L A B$ & $7.22 \pm 0.26^{\mathrm{a}}$ & $3.08 \pm 0.06^{c}$ & ND & $3.61 \pm 0.21^{b}$ & ND \\
\hline Cellulase & $5.48 \pm 0.35^{c}$ & $4.73 \pm 0.08^{b}$ & ND & $4.60 \pm 0.23^{\mathrm{a}}$ & ND \\
\hline LAB+cellulase & $6.38 \pm 0.46^{b}$ & $3.43 \pm 0.25^{c}$ & ND & $3.00 \pm 0.13^{b}$ & ND \\
\hline SEM & 0.25 & 0.29 & - & 0.21 & - \\
\hline \multicolumn{6}{|l|}{ Crop means } \\
\hline Corn stover & $6.42 \pm 0.41^{\mathrm{a}}$ & $5.32 \pm 1.06^{a}$ & - & $5.46 \pm 0.35^{a}$ & - \\
\hline Sugarcane top & $5.85 \pm 1.17^{b}$ & $4.18 \pm 1.03^{b}$ & - & $4.14 \pm 0.54^{b}$ & - \\
\hline Additive means & & & - & & - \\
\hline Control & $5.32 \pm 0.39^{c}$ & $6.12 \pm 0.33^{\mathrm{a}}$ & - & $4.83 \pm 0.56^{\mathrm{a}}$ & - \\
\hline$L A B$ & $6.81 \pm 0.26^{a}$ & $3.70 \pm 0.06^{c}$ & - & $4.59 \pm 0.21^{\mathrm{ab}}$ & - \\
\hline Cellulase & $5.96 \pm 0.35^{b}$ & $5.02 \pm 0.08^{b}$ & - & $4.95 \pm 0.23^{\mathrm{a}}$ & - \\
\hline LAB+cellulase & $6.45 \pm 0.46^{c}$ & $4.17 \pm 0.25^{c}$ & - & $4.27 \pm 0.13^{b}$ & - \\
\hline \multicolumn{6}{|c|}{ Significance of main effects and interactions } \\
\hline Crops (C) & 0.0052 & 0.0030 & - & $<0.0001$ & - \\
\hline Additives (A) & $<0.0001$ & 0.0002 & - & 0.0213 & - \\
\hline $\mathrm{C} \times \mathrm{A}$ & 0.0003 & 0.0174 & - & 0.0021 & - \\
\hline
\end{tabular}

Data are means of three silage samples.

cfu, colony-forming unit; FM, fresh matter; ND, not detected; LAB, lactic acid bacteria inoculant FG; Cellulase, Acremonium cellulase; SEM, standard error of the mean; - means the value is zero.

${ }^{\text {a-d }}$ Means \pm standard deviation within columns with different superscript letters differ significantly from each other $(p<0.05)$.

these strains was more than $99.80 \%$ to each other, and less than $98.00 \%$ to other type strains. The AP $50 \mathrm{CH}$ data also supported these results, and these strains and their type strains had similar fermentation patterns. To our knowledge, this is also the first report of natural LAB community on Africa silage.

Certain lactic acid-producing cocci create an aerobic environment suitable for the development of lactobacilli only during the early stages of the silage fermentation process. In contrast, Lactobacilli (rods) are important promoters of lactic acid fermentation for longer periods [23]. Many studies have reported that homofermentative lactobacilli, such as Lactobacillus casei and Lactobacillus plantarum, promote lactic acid fermentation and improve silage quality [1]. In the present study, all corn stover silages were well-preserved, with high lactic acid contents and low $\mathrm{pH}$ values. The factors used to assess fermentation quality included the chemical composition of the corn stover material and the physiological properties of epiphytic LAB. The corn stover had a relatively high WSC content and low LBC, and a high number of epiphytic LAB $\left(>10^{5} \mathrm{cfu} / \mathrm{g}\right.$ of FM). Lactobacillus plantarum are the dominant species naturally distributed in corn stover [25]; this species is a homofermentative type of LAB which grows well under low $\mathrm{pH}$ conditions and produces more lactic acid than other strains [26]. During ensiling, lactobacilli can use sugars to increase the production of lactic acid, thereby reducing the $\mathrm{pH}$ and inhibiting the growth of harmful bacteria, in turn resulting in good-quality silage. On the other hand, the control silage of the sugarcane top was of poor quality, while the microbial additive-treated silages were of good quality. The parameters for assessing fermentation quality include the chemical composition of the crop materials and the physiological properties of the epiphytic LAB. The sugarcane tops had a relatively low WSC content $(<7.85 \%$ of DM), and the $\mathrm{LAB}$ could not ferment sufficient sugar to produce lactic acid (Table 4). Furthermore, the $\mathrm{pH}$ value of this silage did not decrease below 4.0, such that clostridia was present via butyric acid fermentation and ammonia- $\mathrm{N}$ production. However, when the sugarcane top silage was treated with LAB or cellulose, fermentation quality was higher. The cellulase addition could improve fibre degradation to increase WSC as a substrate for $\mathrm{LAB}$, to produce lactic acid and thereby improve fermentation quality. Acremonium cellulase used in this study contain a strong activity of glucanase and pectinase, it can play 
an important role in the silage fermentation process [27]. It is suggested that a decrease in fibre content, including NDF and $\mathrm{ADF}$, in sugarcane top silages underlies this phenomenon. Thus, if crops such as corn have sufficient sugar content, even without the addition of $\mathrm{LAB}$, it would be possible to make a good-quality silage. Therefore, LAB and cellulase might influence the fermentation quality of silage. When the crop byproduct contains an insufficient amount of LAB and WSC, it is necessary to add them for silage fermentation.

The present study mainly focused on silage preparation and ensiling characteristics analysis. The future experiment will be required to study the digestibility of these crop byproduct silages for sheep or cows. Now, the silage or total mixed ration prepared by using local available resources and their evaluation on the digestibility and milk production of dairy cattle is under process. In Africa, agricultural residues from crop production have increased rapidly in recent years [28], in turn increasing the need for efficient use of crop byproducts for economic and environmental reasons. Silage prepared with local crop by-products could be a very effective fermentation technology.

\section{CONCLUSION}

This study suggests that corn stover contained effective LAB species for natural silage fermentation; meanwhile, sugarcane tops could yield good silage with LAB inoculant. Based on the silage fermentation and chemical composition analyses, corn stover and sugarcane tops contain an abundance of nutrients for livestock. Fresh corn stover exhibits good ensiling characteristics and high levels of LAB, which are naturally suited for ensiling and fermentation. Meanwhile, sugarcane tops require $\mathrm{LAB}$ or cellulase additives for silage production. This study suggests that by-products of both crops, as silage, are well-suited for preservation of forage crops and could serve as roughage sources to cover animal feed shortages during the dry season in Africa.

\section{IMPLICATIONS}

The present study reports the community of natural LAB and silage fermentation of corn stover and sugarcane tops, focus on addressing feed shortage during dry season in Africa. Corn stover and sugarcane tops contain an abundance of nutrients for animal. The LAB, especially Lactobacillus plantarum became the dominant bacteria affect silage fermentation after ensiling. Fresh corn stover exhibits good ensiling characteristics and high levels of LAB, which are naturally suited for ensiling and fermentation. Meanwhile, fresh sugarcane tops require LAB or cellulase additives for silage preparation. Based on the bacterial community and silage fermentation analyses, the crop by-products can be well-preserved as silage and have great potential as a feed source for livestock, to cover feed shortages during the dry season in Africa. Silage prepared with local available crop by-product resources could be a very effective fermentation technology for animal production.

\section{CONFLICT OF INTEREST}

We certify that there is no conflict of interest with any financial organization regarding the material discussed in the manuscript.

\section{ACKNOWLEDGMENTS}

This work was supported by the project "Development of sustainable technologies to increase agricultural productivity and improve food security in Africa (Food Security in Africa)", Japan International Research Center for Agricultural Sciences (JIRCAS), Japan, and Instituto de Investigacao Agraria de Moçambique (IIAM), Mozambique.

\section{REFERENCES}

1. Khota W, Pholsen S, Higgs D, Cai Y. Natural lactic acid bacteria population of tropical grasses and their fermentation factor analysis of silage prepared with cellulase and inoculant. J Dairy Sci 2016;99:9768-81. https://doi.org/10.3168/jds.2016-11180

2. Wiedmeier RD, Provenza FD, Burritt EA. Exposure to ammoniated wheat straw as suckling calves improves performance of mature beef cows wintered on ammoniated wheat straw. J Anim Sci 2002;80:2340-8. https://doi.org/10.1093/ansci/80. 9.2340

3. Martin NP, Russelle MP, Powell JM, et al. Invited review: Sustainable forage and grain crop production for the US dairy industry. J Dairy Sci 2017;100:9479-94. https://doi.org/10. 3168/jds.2017-13080

4. FAO Statistical databases (FAOSTAT). Statistical materials of agriculture, fishery and forestry [Internet]. Teikoku-Shyoin Co., Ltd.; c2016 [cited 2016 Dec 21]. Available from: http:// www.fao.org/faostat/en/\#home

5. Chen J, Stokes MR, Wallace CR. Effects of enzyme-inoculant systems on preservation and nutritive value of hay crop and corn silages. J Dairy Sci 1994;77:501-12. https://doi.org/10. 3168/jds.S0022-0302(94)76978-2

6. Goncales M, Nunhes TV, Barbosa LCFM, de Campos FC, de Oliveira OJ. Opportunities and challenges for the use of cleaner production to reduce water consumption in brazilian sugar-energy plants. J Clean Prod 2018;186:353-63. https:// doi.org/10.1016/j.jclepro.2018.03.114

7. Hauser S, Nolte C, Carsky RJ. What role can planted fallows play in the humid and sub-humid zone of west and central Africa? Nutr Cycl Agroecosyst 2006;76:297-318. https://doi. org/10.1007/s10705-005-5630-4 
8. Zhao XL, Liu JH, Liu JJ, et al. Effect of ensiling and silage additives on biogas production and microbial community dynamics during anaerobic digestion of switchgrass. Bioresour Technol 2017;241:349-59. https://doi.org/10.1016/j.biortech.2017. 03.183

9. Li J, Liu R, Chang G, et al. A strategy for the highly efficient production of docosahexaenoic acid by Aurantiochytrium limacinum SR21 using glucose and glycerol as the mixed carbon sources. Bioresour Technol 2015;177:51-7. https:// doi.org/10.1016/j.biortech.2014.11.046

10. Cai Y. Analysis method for silage. In: Japanese Society of Grassland Science, editors. Field and laboratory methods for grassland science. Tokyo, Japan: Tosho Printing Co., Ltd.; 2004. p.279-82.

11. Kozaki M, Uchimura T, Okada S. Experimental manual for lactic acid bacteria. Tokyo, Japan: Tosho Printing Co., Ltd.; 1992. p. 29-72.

12. Tamaoka J, Komagata K. Determination of DNA-base composition by reversed-phase high-performance liquid-chromatography. FEMS Microbiol Lett 1984;25:125-8. https://doi. org/10.1111/j.1574-6968.1984.tb01388.x

13. Thompson JD, Higgins DG, Gibson TJ. Clustal-W: Improving the sensitivity of progressive multiple sequence alignment through sequence weighting, position-specific gap penalties and weight matrix choice. Nucleic Acids Res 1994;22:467380. https://doi.org/10.1093/nar/22.22.4673

14. Association of Official Agricultural Chemists (AOAC). Official methods of analysis of the AOAC International. 16th ed. Washington, MD, USA: AOAC International; 1995.

15. Van Soest PJ, Robertson JB, Lewis BA. Methods for dietary fiber, neutral detergent fiber, and nonstarch polysaccharides in relation to animal nutrition. J Dairy Sci 1991;74:3583-97. https://doi.org/10.3168/jds.s0022-0302(91)78551-2

16. Thomas T. An automated procedure for the determination of soluble carbohydrates in herbage. J Sci Food Agric 1977;28: 639-42. https://doi.org/10.1002/jsfa.2740280711

17. McDonald P, Henderson AR, Heron SJE. The biochemistry of silage. Marlow, UK: Chalcombe Publications; 1981.

18. Roe MB, Sniffen CJ, Chase LE. Techniques for measuring protein fractions in feedstuffs. In: Proceeing Cornell Nutrition. In: Conference for Feed Manufacturers. Department of Animal and Poultry and Avian Sciences; NY, USA: Cornell University; 1990. p. 81-8.

19.Licitra G, Hernandez TM, Van Soest PJ. Standardization of procedures for nitrogen fractionation of ruminant feeds. Anim
Feed Sci Technol 1996;57:347-58. https://doi.org/10.1016/ 0377-8401(95)00837-3

20. Khan RU, Rahman ZU, Javed I, Muhammad F. Effect of vitamins, probiotics and protein level on semen traits and seminal plasma biochemical parameters of post-moult male broiler breeders. Br Poult Sci 2013;54:120-9. https://doi.org/10.1080/ 00071668.2012.753511

21.Steel RG, Torrie JH. Principles and procedures of statistics: a biometrical approach. New York, USA: Mc Graw Hill Company; 1980.

22. Shao T, Ohba N, Shimojo M, Masuda Y. Effects of adding glucose, sorbic acid and pre-fermented juices on the fermentation quality of guineagrass (Panicum maximum jacq.) silages. Asian-Australas J Anim 2004;17:808-13. https://doi.org/10. 5713/ajas.2004.808

23. Cai Y, Benno Y, Ogawa M, Kumai S. Effect of applying lactic acid bacteria isolated from forage crops on fermentation characteristics and aerobic deterioration of silage. J Dairy Sci 1999;82:520-6. https://doi.org/10.3168/jds.S0022-0302(99) 75263-X

24. Wang Z, Dien BS, Rausch KD, Tumbleson ME, Singh V. Improving ethanol yields with deacetylated and two-stage pretreated corn stover and sugarcane bagasse by blending commercial xylose-fermenting and wild type Saccharomyces yeast. Bioresour Technol 2019;282:103-9. https://doi.org/10. 1016/j.biortech.2019.02.123

25.Haag NL, Nagele HJ, Fritz T, Oechsner H. Effects of ensiling treatments on lactic acid production and supplementary methane formation of maize and amaranth-An advanced green biorefining approach. Bioresour Technol 2015;178:217-25. https://doi.org/10.1016/j.biortech.2014.08.048

26. Weiss K, Kroschewski B, Auerbach H. Effects of air exposure, temperature and additives on fermentation characteristics, yeast count, aerobic stability and volatile organic compounds in corn silage. J Dairy Sci 2016;99:8053-69. https://doi.org/ 10.3168/jds.2015-10323

27. Khota W, Pholsen S, Higgs D, Cai Y. Comparative analysis of silage fermentation and in vitro digestibility of tropical grass prepared with Acremonium and Tricoderma species producing cellulases. Asian-Australas J Anim Sci 2018;31:1913-22.

28. Valbuena D, Tui SHK, Erenstein O, et al. Identifying determinants, pressures and trade-offs of crop residue use in mixed smallholder farms in sub-saharan africa and south asia. Agric Syst 2015;134:107-18. https://doi.org/10.1016/j.agsy.2014. 05.013 